\title{
141. 外傷等による腓骨遠位端の骨変化
}

\begin{tabular}{|c|c|c|}
\hline 国府台整形外科 & 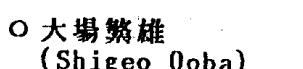 & \\
\hline 謷田术立稳合病浣 & $\begin{array}{l}\text { 新阔菒志 } \\
\text { (Ekishi Shinma) }\end{array}$ & $\begin{array}{l}\text { 光部晶他 } \\
\text { (Ak inobu }\end{array}$ \\
\hline
\end{tabular}

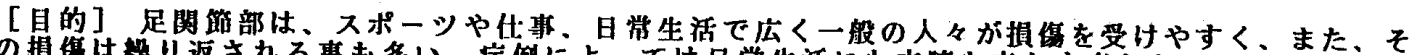

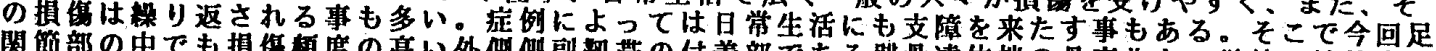

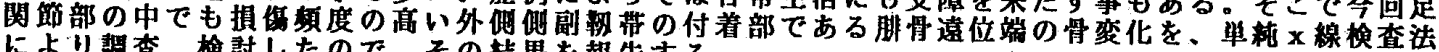

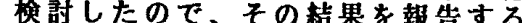

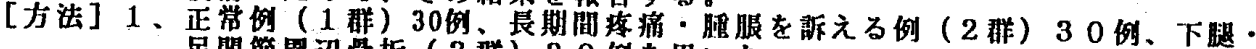
足閔節周辺骨折 ( 3 样) 30 例を用いた。

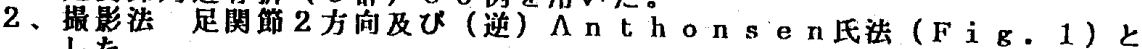
した。

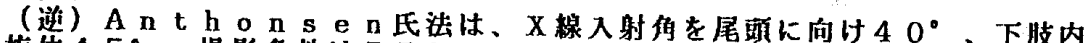

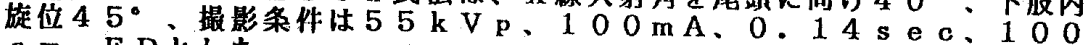

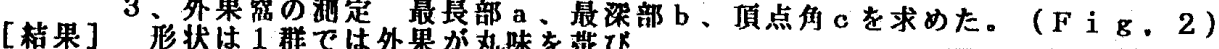

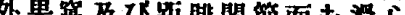

23 和 $\mathrm{i}$. 4$)$

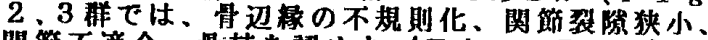
関節不道合、骨碀を㒛めた。( F i g 5,6$)$

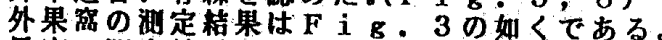

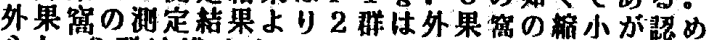

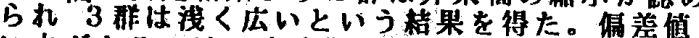
に巾があるのは。疾病期間が㪴例により、3ケ から数年と期间差か大きいためと考方られ、今留の 昩题とした。

[考察]足圈節は荷重間節であり全体重を支え、少行に

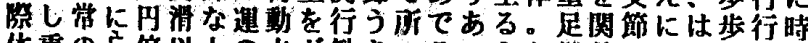

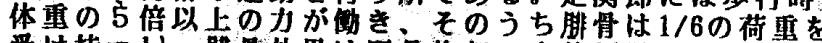

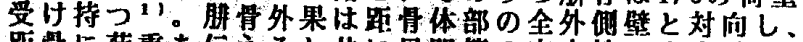

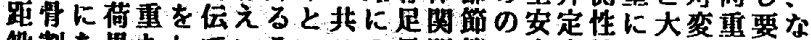
役割を果たしている。この是関節の安定性に奇与している

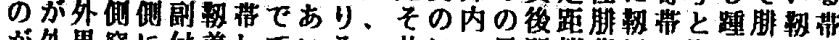
が外果管に付着している。共に、足関節背届で堅張し

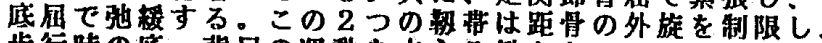

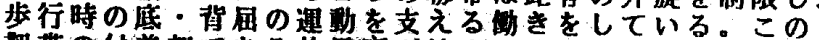

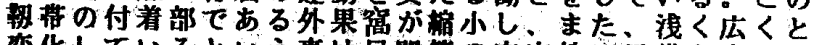

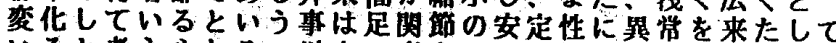
いると考えられる。以上の事より足閣節部の㾢痛、腫䝢が 長期化している度例飞は(遊) Anthonsen氏法による腓

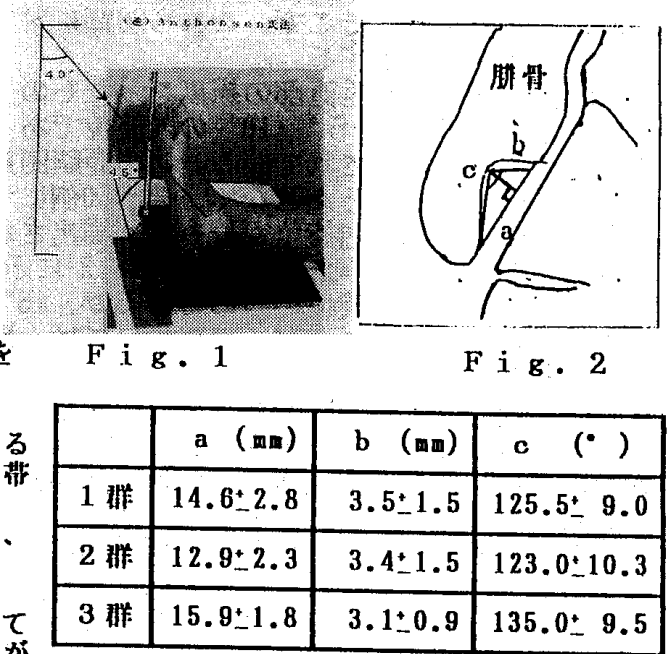

F i g. 3

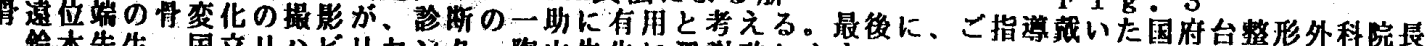

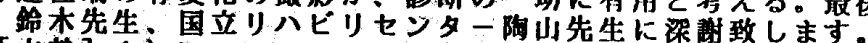

[文赥] 1) Frankel,V.H.\& Nordin,M:Basic biomechanics of the skeletal system 1983 2) 島津晃，他，尼㜀節部の外隻 1986

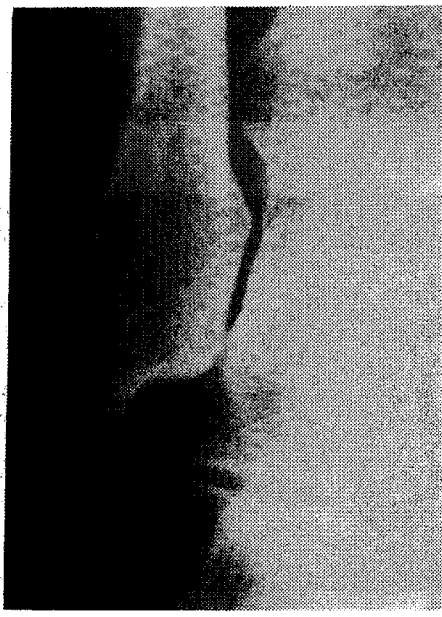

F i g . 4

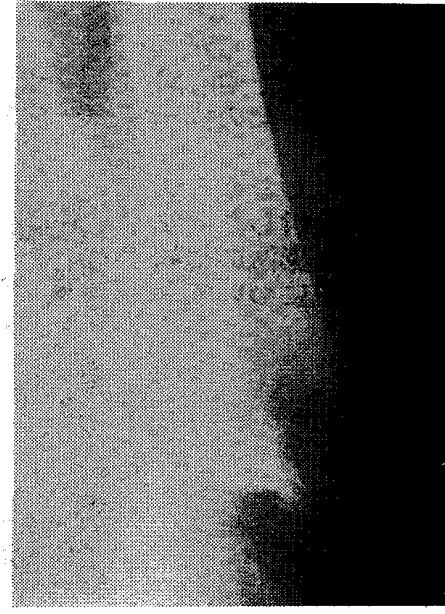

F i g . 5

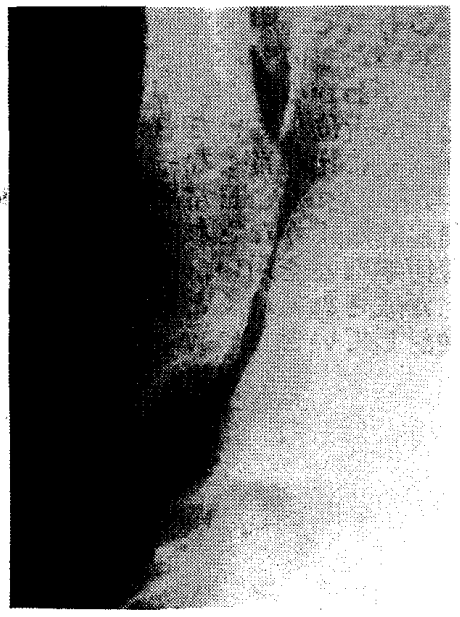

F i g. 6 